\title{
Politician's Strategy After The Pandemic: Strengthening of Patronage Goods in The Form of Social Assistance
}

\author{
Ferhadz Ammar Muhammad \\ Faculty of Social and Political Sciences, Universitas Airlangga, Surabaya, Indonesia \\ e-mail: ferhadz1994@gmail.com
}

\begin{abstract}
This research describes and analyzes the strategies of politicians to attract voter support in electoral politics by providing patronage goods or club goods. The study of this strategy is increasingly relevant considering the Covid-19 pandemic that has emphasized to political actors the importance of social assistance (in Indonesian: bansos,etc.). In some areas, especially those with a flow-political landscape in the form of strong links between parties and social and religious organizations, it shows that local politicians are cooperating with organizations that share a platform with parties to distribute social assistance. However, this research confirms the academics' opinion, such as Edward Aspinall, who believe that giving from politicians with the motive of gaining mass support for party interests, and of course electoral politics, can be said to be an affirmation of patronage democracy. Through comparative analysis with several cases of social assistance distribution that have existed, this study strengthens the main thesis about patronage items as a binding of loyalty between the mass of voters whose numbers are very beneficial for parties and party politicians.
\end{abstract}

Keywords-Social Assistance, Patronage, Clientelism, Party, Organization.

\section{INTRODUCTION}

$\mathrm{T}$ HE Covid-19 pandemic has changes several lines of life, especially the citizens economy. Several business unit and jobs that have been the source of residents' income have had the most significant impact. The threatened welfare condition prompted the government to take the initiative to help through subsidies and the provision of social assistance which summarize in the Social Safety Network (JPS).

In the program which becomes a Government mainstay, Social ministry as frontline, declare three forms of major help ie social support, acceleration of implementation of "Kartu Prakerja", and cutting the electricity bills. Other than Social Ministry, several ministries just like the Ministry of education and Ministry of Manpower also release the support program.

Because of the citizens economic have been helped by this program, so this phenomenon became interesting input for politic actors to get the community attention. Some politicians immediately participating on channeling aids to community, either politicians as government official or politicians as party officials, just like the head of the peoples representative council (DPR) of Republic Indonesia Puan Maharani who went directly to distribute social assistance to the community.

In the political sciens view, Scientist said that the pattern or political system always adapt to environment (David Easton). If this case put in the context of this widespread social assistance provision, then it can be said that the political actors operating within the system will use the social help method as their strategy to get the citizens attention. The long-term goals are clear, that is electoral political interest.

The such a statement get strong claim after the case revealed by Bawaslu. In their explanation to BBC News Indonesia, Bawaslu commissioner namely Ratna Dewi Pettalolo said that her team found several politician cases the point is a candidate for regional head - who put their photos in goods intended as social assistance. The same cases als do by one of PKB party politician when they share thousands of packet of the social assistance in Jember and Lumajang [1]. The assistance is in the form of 40 tons of rice, 8000 packet of staple material, and thousands of personal protective equipment like mask and hand sanitizer.

For the community view, the various of social assistance is helping their financial burden becomes light. The open statement of social assistance contribution is found in several opportunities while asking the citizens opinion.

Meanwhile, electoral politics that demands competition among politicians as well as moments of gaining voter support prompt political actors to seek the right strategy to ensure the votes they need to win electoral elections. In this case, the study of political science on a concept called influential representation.

As it basic meanings, representation means "acting for" [2] If this representation is used for explore the endogenous factor behind such practices, then it Will show the assumsion about political actor behavior that use social assistance as their program in this pandemic just to reap certain things oriented. It seems that in the context of political parties, the interest in getting mass votes for victory in electoral politics is the most rational "object of struggle" to be discussed.

Furthermore, the choice of social assistance as the medium for launching this motive is the community psychology which has a quick response in terms of economic. It is quite clear that the economy is the most influential basis in shaping other orders, such as politics. Based on the analysis using the Marxist approach, the economy is referred to as the infrastructure of life on which a superstructure stands in the form of other aspects of life. Just like Vedi Hadiz said that the mixture between economy and politics was so thick in the post-reform era [3]. In the realm of political praxis, this can be found in the presence of a vote buying pattern that is coherent with the rationality of society in choosing, or what is called the rational choice view.

Therefore, the impact behind the change in looking at the economic aspects of politics gives rise to pragmatic reasoning, where people will only choose candidates or 
people's preferences lead to certain parties that provide them with social security through economic welfare - even if in the short term in the form of assistance, or in the language of Aspinall. called "retail". It is hoped that with the social assistance provided for the community in the midst of the crisis due to Covid-19, politicians and parties will benefit in the form of people's preferences to channel their votes in elections.

In some cases, social assistance is provided by politicians in society who have loyalties to it, or at least people who have the possibility to be embraced even though they are not formal loyalists and sympathizers. As happened in Brebes, which showed a PKB politician distributing Educational Operational Assistance to Islamic boarding schools. As stated by some political analysts, such as Aspinall, pesantren is the basis of PKB loyalists [4].

In this way, the provision of assistance by PKB politicians can also be interpreted as an effort to bind the loyalty of the masses of voters to politicians and parties. Because pesantren has become an institution that has a very strong influence in society, interested parties always try to approach the pesantren so that their agenda can run smoothly.

Rizkika Lhena Darwin successfully demonstrated the same thing through a thesis that supports this argument. Candidates or politicians often visit several institutions, especially pesantren, with many programs that can attract the attention of pesantren to be willing to support them and - thus mobilize their mass [5].

This study will analyze how social assistance, which was originally intended to a priori help overcome the economic threat of citizens, is used at the same time as club goods or patronage items that have an electoral political impact for politicians.

\section{METHOD}

This study using qualitative method which purpose to understand the object deeply. Such research has implications for the approach the researcher uses, namely the qualitative approach. The qualitative method is also defined by Bogdan and Taylor - quoted by Moleong - as a series of research procedures that produce descriptive data in either written or oral form from people as the unit or behavior being observed [9].

This is considered appropriate, because in particular qualitative research consists of investigations that seek answers to questions, systematically use a standard set of procedures to answer questions, gather evidence, and produce findings. Therefore, qualitative research is very effective in obtaining information about values, opinions, behavior, and certain social contexts [9].

Often times such models are called descriptive-analytic methods. McCall and Simmons provide the essential elements of this method. First, using concepts, propositions, and empirical generalizations from a scientific theory. Second, using collections, classifications, and facts systematically. Third, produce new empirical generalizations based on these data. This analytical description method is considered by both of them to be the most effective alternative, armed with research work efficiency and its application strength in the field [10].

The resulting data will be processed using the techniques proposed by Miles and Huberman. According to them, activities in data analysis are data reduction (summarizing, selecting, and focusing data), display data (presenting data, such as describing it), and conclusion drawing / verification (concluding findings). So that the activities in qualitative data analysis in this study were carried out interactively and continued continuously to completion [11].

This research uses clientelism as the main theoretical framework. In this study, researchers agree with the definition put forward by Aspinall and Berenschot that clientelism is “... The practice of exchanging material resources or benefits (money, goods, jobs or positions, public services, contracts with government institutions, etc.) with political support (votes, donations of campaign funds, campaign support, etc.)." While patronage “... refers specifically to goods or benefits that are exchanged through clientelistic practices"[12].

Actually, patronage often refers to the practice of exchanging non-programmatic goods, such as those sourced from a candidate's personal finances or party coffers. However, seen from the modus operandi in clientelistic practices, programmatic goods such as social assistance are gates that can lead to clientelistic practices, because they have the potential to be diverted into patronage goods. Everything is seen from whether the provision of patronage items is based on careful calculation or identification of the mass of recipients regarding their loyalty and certainty in choosing the beneficiary or just a mere distribution of assistance in general without any selection and identification. If the answer is the first one, then the practice is clientelistic using patronage goods as a binder.

Thus it can be identified that there are at least three elements in clientelism, namely contingency or reciprocity, hierarchical which means that power relations between patrons and clients are carried out unequally like politicians and receiving societies, and the repetition aspect which means that the practice is repeated in every edition of the general election. The latter element becomes the researcher's point of emphasis based on the assumption that this social assistance does not stop only during the pandemic, but will be repeatedly applied by politicians in their strategies, because it has proven successful in getting high attention from people who have a "rational choice" view.

In connection with this patronage, the research conducted by Lucky Dhandy Yudha Kusuma entitled Afiliasi Politik Kiai Nahdlatul Ulama dalam Pemenangan Pasangan IrsyadGagah pada Pilkada Kabupaten Pasuruan 2013 very important to accommodated[13]

Armed with patronage theory and the concept of religious elites during the general election, Lucky made important findings, namely that there was a patron-client pattern between NU kiai and PKB. The provision of assistance and guarantees that promises to be a patronage item is operated.

The thing that binds the two of them apart from needing each other is also the inevitable existence of material or economic offers. But more than that, through a psychological approach, the Irsyad-Gagah pair received support from the 
NU kiai not only because of the PKB factor, but because Irsyad-Gagah had a number of platforms that were in line with the NU kiai.

That means, in the study of patronage, politicians will only give the benefits they have to supporters who are attached, as binders, and sympathizers who are willing to vote, as a contract. The key word is clear, namely, "You will get this item only if you support and / or choose me".

As a guideline for research that has been conducted by academics, Mulyadi Sumarto's study is written in his book entitled "Perlindungan Sosial dan Klientelisme: Makna Politik Bantuan Tunai dalam Pemilihan Umum" researchers will develop.

In the research published at the end of Susilo Bambang Yudhoyono and Jusuf Kalla's administration, Mulyadi departed from Wood's (2004) thesis which argued that the more social protection distribution programs managed directly by the government, it should be able to reduce the practice of clientelism, because it reduces client dependence on patronage items from its patrons.

But in fact, in the case of Direct Cash Assistance (BLT), orientation to answer the needs and rights (entitlement) of public welfare has been transferred to become a kind of patronage item from the political elite who used it as a vote buyer to win the 2009 presidential election.

According to Mulyadi, countries in Latin America have actually pursued the same thing, one of which is Brazil with conditional cash transfers (CCT). Such programs are also used as a patronage for candidates, especially the incumbent, to win the presidential election (pilpres). President Lula in Brazil, for example, used the CCT program known as the Bolsa Familia to succeed his ambition to run in the 2006 elections.

The difference is that in Indonesia, the modus operandi of clientelism and patronage democracy in Brazil is very open and persistent, as when President Lula admitted frankly that his victory was inseparable from his ability to run the Bolsa Familia. Meanwhile in Indonesia, such practices run informally, incidentally, and are not equally felt by the wider community.

Next, the two developments in clientelism studies below will serve as guidelines in capturing the strong reasons behind the operationalization of patronage items carried out by politicians.

\section{1) Culturalist}

At this time, research on political clientelism uses a culturalist approach, in the sense that the relationship between two actors (patron and client) is largely determined by the extent to which cultural norms are carried out by members of society.

James Scott, for example, examines the patron-client relationship practiced by landlords and farmers. Both are involved in the patron-client relationship which forms the basis of clientelistic practice, because there is an element of reciprocity and the transfer of economic and political choice autonomy through the norm of 'respect' [14].

Actually, this first wave cannot be said to be political clientelism because its existence is so smooth that it is not realized by farmers. The thing that underlies the relationship between the two is not a political tendency - although in some rural (rural) areas landlords often benefit politically in the process of selecting positions - but the norm of reciprocity, because the patron has provided the land for the peasants, the peasants must automatically benefit the patrons. In addition, this practice has three fundamental weaknesses, so that when it is drawn into an analysis of the face of modern clientelism, it is easily refuted. These weaknesses are that there is an imbalance in the exchange between the two partners which expresses and reflects differences in relative wealth, power, and status; A sustainable pattern of reciprocity that builds and strengthens patron-client bonds often creates trust and affection that are bound by primordial values, whereas in modern clientelist practice it is political and economic values that underlie network exchanges; and finally, the patronclient relationship is carried out by a widespread "whole person", rather than an explicitly impersonal contractual relationship [14].

\section{2) Marketist}

In this wave, political scientists began to see clientelism as strongly associated with massive industrial development. The industrial upheaval on all fronts has had a significant influence on political considerations held by society. They began to shift from cultural considerations to rational. Thus, this second wave represents what is called by Aspinall as the marketies approach [12].

The appearance of this approach just as we said concurrent with behavior of choosing a rational society in identifying itself to the "whom". Researchers who believe that the marketies approach is the basis for clientelists' behaviors and patronage democracy, among them Susan stokes, who considered rational issues such as economic growth and development to be the reason for their clientelism practice [15].

This principle of rationality in electoral politics by Saiful Mujani and Liddle (2010) is defined as identification by voters to a set of priorities of goals, such as economic growth, general prosperity, national unity, education, and the rule of law [16]. Meaning in clientelist practice, the client decides to accept or not an offer from the patron based on a consideration of the merits to be obtained. So this model completely nullifies where the 'respect' norm is, even on a limited scale, while also challenging the more appropriate culturalist approach occurred during the "politik aliran" (politics of flows).

In fact, the "politik aliran" (politics of flows) is still in operation today through the fact that the giving of goods by politicians is usually degenerated by like-minded supporters, such as fellow NU. However, the marketies approach is more than just ideological considerations such as the culturalist approach claims, where the 'willing' element behind the practice is dominant. Because based on the marketies' opinion, what bonds and maintains the clientelism's relationship is a patronage supplied either to its loyalist supporters or simply to sympathizer.

Loyalists are more concerned yet, as in electoral politics just maintaining the base is a step forward. For example, why PKB that claiming to represent NU organization has never been consistent in winning elections between parties with a religious organization as well, even NU are huge. This fact is 
recognized by politicians today, so they use more strategy according to the marketies approach than just the kulturalis.

However, both approaches will remain adoption researchers with the operation of culturalis as a guide to understanding clientelism that remain in good standing with prospective supporters, regardless of whether they have social assistance or not, and marketis as the main approach that will further pose social assistance into a politician's strategy.

\section{RESULT AND DISCUSSION}

Researcher began the discussion by showing one of the results of an interview with one source when asked how social assistence's distribution patterns occurred at the local in pandemic.

Kalau sepengalaman saya bantuan sosial di masyarakat itu digunakan untuk orang-orang tertentu. Semisal gini, dari pemerintah desa itu mengadakan seperti kemarin ada BLT atau sejenisnya, itu yang dapat justru sanak famili pejabat desa. Dari situ timbul kecemburuan sosial, dan itu bahkan membuat masyarakat bingung. Kenapa kok cuma orang ini yang dapat? Kok gak diperuntukan untuk orang ini yang lebih pantas dapat? Kemarin kan menonjol sekali, kok yang dapat hanya beberapa, itu pun yang dekat-dekat dengan pejabat balai desa. (In my experience, the social assistance in the community is used for certain people. For example, the village government held it yesterday there was a BLT or something, and who received it was the village official's relatives. From there, the social jealousy is raising and it even bewildered the public. Why only those in particular who receive? Why not give it to people who are more deserving? It seems very evident that only people who had a close relationship with the village official received it yesterday. (Interview, 16th of November 2020)

The statement "only people who had a close relationship with the village official" Indicating what is called by Aspinall with a modified product of patronage as one of those on the clientelist's network, that is between politicians and supporters. This network form interconnected systems that contain elements of iteration, status inequality and reciprocal. So, the sources' experience that obtained by researcher confirms that networks formed by actors involved will become more strongly run in accordance with the three elements above when bound with a chain or bond.

Nonetheless, the source also claims that people who receive no social assistance, or receiving it too late, only did oral or mouth-to-mouth comments, not up to the immediate protest.This is where the culturalist clientelist's view is relevant. The beneficiaries who are close with village officials and other communities are in dilemma. There are a lot of causes that have grown back to the practice in the source area evidently, that is "recompense" or "loath" and the legacy of past political practices preserved to the present day by both the village elite and the majority of people who maintained the status quo.

In the larger landscape, national politics, though frequently referred to in legal terms, the practice of clientelism has never completely disappeared from democratic lives, even more dilemma. Political actors, both personally and those tied to the party were systematically distributing only social assistance to the supporters, especially those who had become party loyalists. Unfortunately, in the marketies era loyalty can be cultivated only on a mutually profitable network, as PKB showed with NU loyalist base. In addition to loyalist supporters, politicians are also willing to distribute their assistance to communities that identified are have a strong posibility to pass their vote on to certain social givers.

The pattern of the politician sets on social assistance refers to Susan C Stoke's faith. Stokes that clientelism is a condition in which the party offers material gain only on the condition that the beneficiaries return the favor through voting or other forms of political support. Simply in electoral political practice, constituents have the necessary vote for a candidate's victory, which means the candidate has the 'benefits' of the resources the constituents need, and the constituents have the' influence 'to distribute votes for the candidates. In the practical domain it is most evident in the relational relationship between politicians and mob whether loyal like a particular organization, until the floating mass which can be pulled out to be sympathizers by largess of patronage or an item used as a medium of exchange.

Further, the clientelism overshadows the beneficiary to the point of feeling suffers a punishment when be an apostate from an implicit bargaining about the vote profit of the giver [15]. It runs so tight, even beneficiaries who do not give political preference to politicians who give patronage to others are liable, especially through social means. For example, as some frequent complaints, the blacklist of the beneficiaries of social assistance next period.

In the orba period, such punishments also occurred mainly for civil officials who did not distribute their voice to Golkar. But, the condition was different with the orba period where the clientelism is concentrated on an institution of state, the practice has become more murous and opaque since the reformation, where classes once suppressed by minimalist civil-society systems, instantly consolidating the spreading of new parties. That represents two conditions. At first glance reflect citizen aspirations of being articulate, but on the other hand, as a result of legacy cultures of the orba, there has been a need for political cooperation and multiparty complexity, clients are back in the growing category of the "influence network" and "benefit network" between patrons and clients in the interest of elections.

Unfortunately, the reformation era that claimed gives a legal certainty Instead of producing certainty in the political sphere of electoral politics, politicians should work harder to solidify their influence in society, as they are in a position of open competition between one politician and another that's called by Aspinall colonnade clientelism. The problem is that the escalation of the electoral competition is accompanied by the ideological degradation of voters, which means law is winning or losing, based on the extent to which politicians benefit the voters. Surely the benefits here are a concrete representation of the economic language of daily society. Therefore, short-term social assistance, as long as people need it, is a targeted strategy.

In order not to consume significant amounts of force, politicians then determine which institutions have the powerful influence to give a patronage product with social assistance. In this case, social-religious organizations and communities within society are the most rational institutions for cooperation. Beside, this collaboration makes it 
unnecessary for politicians to "pouring out" large sums of money, it also makes it easier for the party to control voters or constituent masses. The organization clearly knows the consequences of disobedience to the agreement that was included. Because in the grassroot landscape has a dictum explaining that in the political activities carried out by politicians cannot be free of interest and motives.

Religious organizations, especially boarding schools because it has enormous amounts played a significant role. At least there are two influence factors, the first is a definite mass of religious organizations. Such as boarding school, As an Indonesian subculture, boarding schools are home to a high degree of public education. Second, the influence of religious leaders to create a popular crowd. The simple argument is also acknowledged by Hirokoshi (1976), which says that the figure of a religion clearly often plays a role as a decisionmaker or policy aggregate that has great influence, thus being able to lead people, especially in the village settings, to carry out his decision [17].

In this case, the culturalist and the marketist go side by side. As Arya Fernandes has pointed out that the recent election edition represents a shift in primordial issues to economic and development issues used by each competitor through socialization and public communication, especially in campaigns. Nevertheless, arya has also pointed out that identity aspects are also attached to the idea of tying solidarity through non-rational aspect or market, which is psychological [18].

At least finds in this study refer to two of the most vital causes of party institutions being less effective. The spreading of the social assistance practice was converted into a patronage material that can be traded in the clientelist network by politicians indicating a party machine that was lacking in compliance with institutional regulations. The argument is be reinforced by political scientists who have special attention to this institutionalization. Vicky Randall and Lars Svasand through a study entitled Party Institutionalization in New Democracies emphasizes the importance of the party's institutionalization aspect according to its definition,that is "the process by which the party become established in terms of both integrated patterns on behaviour and of attitude and culture." [19].

According to the records (annotate) Scott Mainwaring, there are four dimensions of the party's institutional success. First, institutionalized parties are more mature when it comes to a conflict management. The differences of opinion and attitude among the internal party elite did not lead to delegitimizing and disunity. Second, the institutionalized party has strong roots in society. Ideology and party platforms are accepted by the communities that are the main voter bases. Third, the party is accepted and acknowledged by the public as a representation of the public interest guaranteed in democracy. Fourth, the party ran a routine of work according to the structure and procedures clearly agreed upon by the members in general, not just a group of a party elite [20].

The politicians' rule of game should be inside the institutional corridor already implemented by the party. Unfortunately, the most important aspect of the institutionalization of ideological identity is increasingly distorted by a brief view of short-term interests, such as an incidental gift, one of them social assistance.

Based on das sollen, the political party not only owned but also ran ideologies, platforms and mass bases that understood the direction of the party's struggle. This infusi degree of value is relevant to track the extent to which the party has connections with popular groups, such as religious communities, professional communities, and ethnic communities, while also understanding how party members act in accessing resources, whether instrumentalists (hoping for resources or material reward) are ideological enough.

This study found that instrumentalists aspect were more dominant than ideological aspects. Once more, as presented at the outset of this writing, the phenomenon roved with the public's perception of increasingly powerful money exchanges.

The infusi failure of value lies with a listlessness of the party instills value and screams itself to the public, so the public is unable to identify it. What the public thought eventually produced pameo, was that the activity of politicians and electoral elections was a party to profit in the form of material, while one receives only, or if given to an organization and a community, then the time span can be longer, but with greater quantity and quality delivery of the goods.

Let's look at Aspinall's research that in this case strongly supports the findings of researcher. In an election strategy carried out by one of the candidates for the position of the region's representatives (DPRD) east Java to be re-elected, the candidates apply what is called a government patronage program. Uniquely, as researchers have noted earlier, the relational aspect with an organization of the religious activists' network that the candidate was able to get while in college. The candidate frankly admits that he was inspired by an effective strategy of Ikhwanul Muslimin of holding a campaign using religious bases and the work of the loyalists to influence other floating masses. Then, after the first period of the candidate's election had been successfully selected, he immediately initiated a relief strategy for his constituents and his networks in the interest of running for the next period through effective use of the social items already provided in government programs. Aspinall wrote:

Sebagai hasil dari usahanya dalam memberikan projek dan manfaat berskala kecil yang didanai oleh program pemerintah semacam ini, basis dukungannya merambah jauh ke daerah perdesaan. Selama periode lima tahun pertamanya, bahkan ketika mengunjungi daerah pegunungan terpencil dengan mengendarai sepeda motornya, setelah membangun kontrak awal, ia merawat jaringan komunikasi dengan penerima manfaat, baik melalui komunikasi elektronik maupun melalui kunjungan yang ia lakukan beberapa kali. (As a result of its efforts to provide projects and small scaled benefits by such a government program, this support base extends far into the rural. During his first five-year period, even while visiting remote mountain areas on his motorbike, after building a first contract, he maintained a network of communication with the beneficiaries, both through electronic communication and through visits made by him several times) [12].

The policy taken by the candidates in east Java strengthened the Mainwaring and Torcal statements that said, "In the advanced industrial democracies, citizen evaluations 
of leaders contain programmatic, ideological, or party identification components"[20].

\section{CONCLUSION}

This study has successfully answered the principal research question, which is the extent that social assistance will be the focus for politicians in building the voting strategies for the interests of electoral politics. The data that researcher have successfully collected show the Indonesian political landscape at the time of the covid-19 pandemic where politicians, whether individual actors, government officials, or party administrators are using social assistance to create a network with constituents, while building an image for ease of mobilization during an electroal political competition.

The intensity of social assistance giving in a short time is clearly affecting politicians, at least giving room for the creation of connections between politicians and electoral bases. Although social assistance may be given to each subject, both individual and community, but politicians more travel distribution routes to organizations, especially socioreligious, because they are viewed as having loyalties that can be cultivated over a long period. In addition, the organization offers a powerful network of influence to the members who are ready to trade with the patronage benefit network, either one at a time or a big program, like pork barrel.

This find is important to be accommodated by public policy makers who are inside the government system. For the government, this indicates that assistance and government programs should be overseen more clearly so that there are no social assistance anomalies. It is necessary to go forward to a deep research to analyze some of the undisclosed factors, like the effectiveness of a patronage in local settings after the election and monitoring of civil society groups in escorting the delivery of social assistance from the governments by officials and politicians.

\section{REFERENCES}

[1] BBC. Virus corona dan bantuan sosial: Foto kepala daerah di kemasan bansos, 'kampanye terselubung' yang dapat dipidanakan. https://www.bbc.com/indonesia/indonesia-52533254

[2] N. Suseno, Representasi Politik: Perkembangan dari Ajektiva ke Teori, Jakarta: Puskapol FISIP UI, 2013

[3] V. R. Hadiz, Dinamika Kekuasaan: Ekonomi Politik Indonesia PascaSoeharto, Jakarta: LP3ES, 2005

[4] E. Aspinall and M. Sukmajati, Politik Uang di Indonesia: Patronase dan Klientelisme pada Pemilu Legislatif 2014, Yogyakarta: Polgov, 2015

[5] R. L. Darwin, "Bireuen, Aceh: Dampak dari Politik Pasca Konflik dan Kemerosotan Partai Aceh", Politik Uang di Indonesia: Patronase dan Klientelisme pada Pemilu Legislatif 2014, Yogyakarta: Polgov, 2015

[9] L. J. Moleong, Metode Penelitian Kualitatif, Bandung: PT Remaja Rosdakarya, 2007

[10] D. Mulyana, Metode Penelitian Kualitatif: Paradigma Baru Ilmu Komunikasi dan Ilmu Sosial Lainnya, Bandung: PT Remaja Rosdakarya, 2010

[11] M. B. Miles and A. M. Huberman, Analisis Data Kualitatif, 1992, Jakarta: UI Press

[12] E. Aspinall dan W. Berenschot, Democracy for Sale; Pemilihan Umum, Klientelisme, dan Negara di Indonesia, Jakarta: Yayasan Obor Indonesia, 2019

[13] L. D. Y. Kusuma, "Afiliasi politik kiai nahdlatul ulama dalam pemenangan pasangan irsyad-gagah pada pilkada kabupaten pasuruan 2013", Jurnal Unair, vol. 3, no. 1, pp. 95-105, 2014

[14] J. Scott, "Patron-client politics and political change in southeast asia", Journal The American Political Science Review, vol. 66, no. 1, 1972

[15] S. C. Stokes, dkk, Brokers, Voters, and Clientelism: The Puzzle of Distributive Politics, New York. Cambridge University, 2013.

[16] S. Mujani dan R. W. Liddle, "Personalities, parties, and voters", Journal of Democracy, vol. 21, no. 2, 2010.

[17] H. Horikoshi, Kyai dan Perubahan Sosial, Jakarta: P3M, 1987.

[18] A. Fernandes, "Politik Identitas dalam Pemilu 2019 : Proyeksi dan Efektivitas", CSIS Election Series, no.1, 2019.

[19] V. Randall dan L. Svåsand, "Party Institutionalization in New Democracies", Journal Party Politics, vol. 8, no. 1, 2002.

[20] S. Mainwaring dan M. Torcal, "Party System Institutionalization and Party System Theory After the Third Wave of Democratization", Hand Book of Party Politics, London: Sage, 2006. 